\title{
Széchenyi az erdélyi magyar szellemi életben a két háború között
}

„Az imádkozás ideje eltelt. És el az átkozódás ideje is. Az álmodozásnak is vége és a sírásnak is... Fölébredtünk. Látni akarunk tisztán. Szembe akarunk nézni az Êlettel, tisztában akarunk lenni helyzetünkkel. Ösmerni akarjuk magunkat” — irták a méltán történelmi jelentốségûnek tekintett Kiáltó Szó címû röpirat szerzôi 1921-ben.I A Kós Károlytól fogalmazott komor mondatok a kisebbségi talpraállás és a közösségi megszervezôdés követelményét valló, a közéleti nekigyürkőzés és a történelmi kárhozattal való szembefeszülés parancsát elsôkként fölvállaló polgári-plebejus erōk és októbristademokrata értelmiségiek álláspontját fejezték ki. Az 1918-19-es nagy földcsuszamlás következményeivel való józan számvetés igénye $s$ a kisebbséggé lett magyarság történelemformáló szándéka szövegezổött meg bennük. A közösségi-közéleti aktivizmus októbrista-polgári képviselôi és a kisebbségi kibontakozás transzilvanista-demokrata szorgalmazói a „tisztán akarunk látni” igényét és a „tisztán kell látnunk” parancsát állították egykoron szembe az erdélyi magyarság soraiban eluralkodó kétségbeeséssel és rezignáltsággal. A „tisztánlátás” öntudata, a helyzet logikájából adódó gyakorlati teendōk többé-kevésbé következetes végiggondolása határozta meg e rétegek közéleti-politikai kezdeményezéseit is. A „tisztánlátás” jegyében alapítottak lapokat és hívtak életre mûvelôdési intézményeket, teremtettek úgyszólván a semmibōl az erdélyi magyarság számára új közösségi létkereteket. A „tisztánlátás” eszméje vezérelte ổket, midôn igyekeztek leszámolni a meddô felelôsségi vádaskodásokkal és a világfájdalmas attitűdökkel, a sértettségérzés kóros állandósulásával és a bénító csüggetegséggel. A „tisztánlátás" posztulátumához igazodtak akkor is, amikor a kivándorlók tömegeinek láttán riadóztatni próbálták a közvéleményt és a közösségi lelkiismeretet, mondván, hogy „meg kell kötni az omladozó gátat, mert útját kell állani a veszedelmes áradatnak, amely életerổt csapol le a mi népünkbôl és elbírhatatlan terhet visz át a konszolidálódás nehézségeivel birkózó túlsó országnak a nyakába" 2 . Nem kétséges, hogy a kisebbségi sorsba jutott erdélyi magyarság számára az 1918-19 utảni években a „tisztánlátás” volt az egyik legfổbb történelmi deziderátum: a közösségi megmaradás alapvetô feltétele testesült meg benne.

A Kiáltó Szó megjelenése s a "tisztánlátás” követelményét gyakorlati tettekre váltó kisebbségi-közéleti szervezkedés megindulása után még másfél évtized sem telt el, amikor a nagy gazdasági világválság társadalmi-politikai feszültségekkel terhes légkörében ismét felhangzott az erdélyi magyar szellemi életben a programjellegũ jelszó: „Tisztán akarunk látni!" 1933-ban László Dezsổ, az Erdélyi Fiatalok egyik alapítója és szerkesztổje, a korszak nemzedéki forrongásának hangadó egyénisége a közismert Ady-vers híres kulcssorát választotta frissen megjelent könyvecskéje címéül: Akarom: tisztán lássatok. A könyvecske alcíme f́gy szólt: Széchenyi István és a magyar jelen. Nem a századelō Magyarországán igéihez megértést keresổ költổ panaszos sóhaját akarta megidézni László Dezsố, s a „legnagyobb magyar" eszmevilágát is inkább csak alapozásként használta egy új generációs cselekvésprogram megfogalmazásảhoz. Széchenyire hivatkozott és vele

1 Kós Károly-Zágoni István-Paál Árpád: Kiáltó Szó. A magyarság útja. A politikai aktivitás rendszere. E. ก. 3. Hozzáférhetố újabb kiadása: Kốbốl, fából házat ... igékbốl várat (n memoriam Kós Károly 1883-1983). Bp. 1983. 91-92.

2 Alkotni. (Vezércikk) Keleti Újság 1920. október 10. 
érvelt, az ổ tetteit és törekvéseit, közösségi erkölcsét és közéleti magatartását állította példaként az olvasó elé, de igazából a maga nemzedékének életérzését és aktivitáskészségét öntötte mondatokba. Lázadás feszített a szavaiban. „De egyszer már nekünk is élnünk kell. A halott gondolatokat el kell sepernünk, a halálosan megfertôzött magyar levegổt félre kell sodornunk, a halottak kezébổl élō̉ kezekbe kell az evezőket általvennünk!" - írta könyvének felhívásszerü elổszavában László Dezsổ, s indulatospatetikus mondataiban ott lüktetett a harmincas évek elejének egész szellemi légköre, a korszak fiatal magyar értelmiségének minden gondja és zaklatottsága. Ott volt bennük egy nemzedék csalódottsága és meghasonlottsága, de ott volt az az általános kōzéleti atmoszféra és kollíziós társadalomlélektani állapot is, amely a romániai magyar kisebbséget a harmincas évek elején egészében jellemezte.

Mi sem áll távolabb tôlünk, mint az a szándék, hogy véletlenszerü stiláris konszonanciák, illetve megfogalmazásbeli egybecsengés alapján közvetlen összefüggést konstruáljunk vagy egyenlôségjelet tegyünk két történelmi helyzet vagy politikai-szellemi megnyilatkozás közé. Kisebbségi létviszonyok között a „tisztánlátás” kétségkívül a közösségi megmaradás egyik állandó feltételét jelenti, úgyszólván idő̉tlen közéleti követelmény, majdhogynem metafizikai parancs testesül meg benne. De itt a „tisztán akarunk látni”, illetve a „tisztán kell látnunk” 1918-19 utáni deziderátumának a harmincas évek elején bekövetkezõ hangsúlyos visszatértét, nemzedéki lázadást is hordozó reinkarnációját csak annak az ellentmondásos helyzetalakulásnak a megvilágítása végett idéztük fel, amelynek folytán Széchenyi István eszmei öröksége a két világháború közötti erdélyi magyar szellemi élet középpontjába került, s a hozzá való viszonyulás egy egész értelmiségi generáció alapkérdésévé vált.

A Kiáltó Szó erkölcsi viaskodásban fogant és felelổsségtudatban született szép mondatainak, valamint a László Dezsố-könyv Adytól kölcsönzött címének egybehangzása mögött valóra nem vált közösségi remények, elszalasztơt közéleti lehetőségek, csalódások és megcsalattatások, végsō fokon pedig az addigi kisebbségi magyar politika eredménytelensége húzódott meg. Se terünk, se lehetôségünk nincs itt arra, hogy a látszólag pusztán megfogalmazásbeli konszonancia hátterében található társadalmitörténelmi tartalmakat, egy évtized politikai ballépéseit és kisebbségi csatavesztéseit részletekbe menően áttekintsük. Csak megemlíteni tudjuk, de behatóan elemezni nem, hogy míg egyfelôl a demokratikus-plebejus kibontakozásra alapozott kisebbségi kőzélet eszméjét zátonyra futtatta a konzervatív szüklátókörüség és a nemzetállami érdek, addig másfelôl az arisztokratikus szalonpolitizálás, a kulisszák mögötti egyezkedések taktikảja meddổnek bizonyult. Bár tudjuk, hogy citátumokkal nem lehet analíziseket helyettesíteni, itt kénytelenek vagyunk mégis ehhez a módszerhez folyamodni. Szentimrei Jenốt idézzük, aki 1933 karácsonyán az Ellenzék hasábjain ezt írta: „...Azt az utat, melyen idáig jutottunk, nem járhatjuk tovább. Sem gazdasági életben, sem politikában, sem irodalomban és mửvészetben, sem külsổ életünkben, sem odabenn a gondolkodásban. Új tartalom nélkül petyhüdten áll egész eddigvolt magatartásunk tömlổje." ‘ Szentimrei e megállapítása mellé, amelynek kiváltképpen komorrá tette a tónusát az a körülmény, hogy a Megváltó ünnepének áhítatában hangzott el, tegyük oda egy másik közéleti embernek a megállapítását is. Albrecht Dezsō, a késōbbi Hitel-csoportosulás vezéregyénisége más nemzedékhez tartozott, merôben más társadalmi szemléletet és kisebbségpolitikai

${ }^{3}$ László Dezsở: Akarom: tisztán lássatok. Széchenyi Istuán és a magyar jelen. Kvár 1933. 8.

4 Szentimrei Jenô: Kétségek karácsonya. Ellenzék (a továbbiakban: E) 1933. december 24. 
koncepciót képviselt, mint Szentimrei Jenõ, ám mégis hozzá hasonlóan fogalmazott. Egyik 1933-ban megjelent tanulmányában így értékelte a húszas éveket: „Szinte fokról fokra kimutatható, hogyan sekélyesedett el közéletünk, hogyan távolodott napról napra [...] az élettôl, annak lehetôségeitôl és sürgetô kötelességeitôl, hogyan hatott jobban és jobban az önámítás mákonya, amíg oda nem jutottunk, hogy a morfinista hisztériás és beteg dühével utasítottunk el minden kijózanitó és nagy feladatainkra ébresztô kritikát."s

Bár az idézett megfogalmazásoknak igen kemény a hangvételük, csak részben tudják érzékeltetni, hogy a húszas-harmincas évek fordulóján az erdélyi magyarság életében mennyire megsürüsödtek a.gondok és megnổttek a feszültségek. Nagyon sokféle tényezô - kontinentális és helyi jellegư egyaránt - belejátszott abba, hogy a társadalmi-közéleti indulatok roppant mértékben fölhevültek, s a mũvelôdés világa is megkavarodott. Az 1929-33-as gazdasági válságból eredô szociális bajok $\mathrm{s}$ az általuk gerjesztett világnézeti ellentétek az erdélyi magyar kisebbséget is maguk alá teperték és végletesen megosztották. A román jobboldali erổk országos elốretörése, a politikai viszonyok növekvố eldurvulása és a kisebbségi elnyomás súlyosbodása a konzervatív-arisztokratikus közéleti modor addig is nyilvánvaló meddôségét különösen egyértelmủvé tette. Világossá vált, hogy históriai reminiszcenciákra és szũk rétegérdekekre nem lehet tisztességes és hatékony kisebbségvédelmet építeni. Mindehhez egy sor más tényezõ is társult. Ez idôben kezdte hitelét veszteni a transzilvanista ideológia, az a szellemi-közéleti krédó, amely a húszas években úgyszólván hegyeket mozgatott meg. Ekkor lépett színre az a nemzedék, amelyet az Erdélyi Helikon 1931 januárjában megjelentetett ifjúsági száma így jellemzett: „A háború borzalmas élménye legfeljebb a gyermekkor öntudatlanságában érte; amikor látni és tudni kezdett, ez a világ készen volt már." Pásztortưz szerkesztôségének 1930 és 1934 között végbement többszöri megváltozása, vagy Makkai Sándor 1931-ben kiadott Magunk reviziója címû́ munkája egyaránt azt jelezte, hogy az erdélyi magyar kultúra fejlôdése és a közügyi értékszemlélet alakulása válaszúthoz érkezett.

A közéleti indulatok felerősödésének és a szellemi-mûvelốdési törekvések átrendezôdésének, az addigi meggyõzõdések relativizálódásának és az addig jảrt politikai utak eltorlaszolódásának itt vázolt körülményei közepette, az ủj táborszervezỏdések és ủj frontalakulások idején került elốtérbe az erdélyi magyar kultúrában Széchenyi István alakja. Kisebbségünk történeti tudatában jelen volt ugyan addig is, de csak úgy, ahogyan jelen volt a magyar história ezer esztendejének minden más nagysága. Most azonban az eleven szellemi élet középpontjába került, eszmei öröksége viszálykeltổ és viszályoldó tényezôvé vált, majdhogynem lobogó lett a nevébổ. A generációs igényeket hangoztató, de egyszersmind általános társadalmi-politikai reformköveteléseket is megfogalmazó fiatal nemzedék legaktívabb csoportjai àâtták Széchenyit követendỗ példává. Alaki-formális megközelítésbẻn, jelesül a Széchenyi-örökség ideológiai funkciókkal való felruházásának értelmében azt lehet mondani, hogy a "legnagyobb magyar" eszmevilága Erdélyben a harmicas évek elsố felében jutott olyanszerũ szerephez, amilyent az anyaországban már 1919-20 óta bètöltött.

Itt fejtegetésünkben rövid kitérõt kell tennünk, és legalább vázlatosan szólnunk kell arról a sajátos tartalmú Széchenyi-kultuszról, amely 1918-19 után a háborús összeomlás és a militáris fogantatású béke traumájában élổs a konszolidáció hallatlan nehézségeivel 87

5 Albrecht Dezsổ: Kisebbségi reálpolitika. Magyar Kisebbség (a továbbiakban: MK) XII(1933). 3-4, sz 6 Frdélyi Helikon (a továbbiakban: EH) TV(1931) 1. sz. 1 
küszködó Magyarországon alakult ki. Enélkül ugyanis nem érthetnók meg azokat az eszmetörténeti összefüggéseket sem, amelyek a Hitel írójának szellemi örökségét a harmincas évek elejétôl kezdve az erdélyi magyar közéleti-kulturális küzdelmekben oly fontos szerephez juttatták.

Bonyolult társadalmi-társadalomlélektani és mũvelơdési tényezơk határozzák meg, hogy a nemzeti történelem kimagasló egyéniségei és nagy horderejũ eseményei közül a tájékozódási és viszonyítási pontokat keresố utókor számára mikor ki vagy mi válik példaértéküvé. Ugyancsak sokféle körülménytổl függ az is, hogy egy adott idốszakban melyik társadalmi réteg, világnézeti csoportosulás vagy politikai érdektömörülés kinek a nevét írja zászlajára. Mert kiváltképpen a modern társadalmakban, ahol a szociális mezō barázdáltsága s a politikai törekvések megosztottsága a szellemi értékmagatartásrendszerek tekintetében ugyancsak tagoltsággal jár, maga a történelmi hagyomány is megosztott. Amit nemzeti hagyománynak szokás nevezni, az inkább csak a kanti értelemben vett transzcendentális tudatban s esetleg az iskolai tankönyvekben létezik, mert ténylegesen a társadalom különbözô rétegei más-más hagyományokat vallanak a magukénak. A magyar história múltbéli szereplổihez és történéseihez való társadalmiközösségi viszonyulást is csaknem mindig nagyfokú megosztottság jellemezte, ámbár errôll manapság nemigen szokás beszélni. A XVIII. század magyar nemességét ugyanúgy eltérổ értékhorizontú csoportokra, illetve a történelmi múltat különbözôképpen megítélő̉ táborokra tagolta a kuruc-labanc vagy a katolikus-protestáns ellentét, mint ahogyan a XIX. században is elütố történelemlátást eredményezett a függetlenségiek és az aulikusok szembenállása.

Az 1848-49-es forradalom bukásától kezdve, el egészen úgyszólván napiainkig, a magyar nemzeti történelemhez való viszonyulás tekintetében a társadalmi-közösségi értékszempcntok megosztottsága a leghatározottabban a Széchenyi-modell és a Kossuthörökség vitájában nyilvánult meg. A nemzeti létlehetổségek és a társadalomlélektani állapotok alakulásától függỏen a közösségi tudatban hol Kossuthnak, hol Széchenyinek a neve vált ragyogóbbá, de a különbözõ társadalmi csoportok és politikai érdektömörülések egyazon idôszakon belül is eltérổ hangsúlyokkal idézték a két jeles személyiséget. Nagyon hosszúra nyúlna dolgozatunk, ha ennek az immáron másfél százados szemléleti disputának akár csak a legfổbb mozzanatait ismertetni akarnók. Az eddig mondottaknak megfelelổen itt csupán arról kívánunk röviden szólni, hogy az elsố világháborút követô években a történelmi tragédia hangulatában élố Magyarországon miként magasodott Széchenyi alakja a Kossuthé fölé, s lett nevébốl a politikai konszolidáció megalapozását szolgáló program, illetve a lelki konsternáció feloldására hivatott ideológia.

Egyik 1933-ban közölt tanulmányában, amely késốbb is szóba kerül még majd, Makkai Sándor, részint Szekfü Gyula gondolatmenetét követve, áttekintette a Széchenyikultusz dagályainak és apályainak 1848-49 óta egymást követõ változásait, $\mathrm{S}$ megállapította, hogy századunk elején, a nemzeti önelégültség és a liberalizmus problémátlan derülátása közepette a magyar történelmi tudatban Széchenyi István alakja szoborrá, fenntartás nélkül tisztelt, ünnepi áhítattal emlegetett, ám egyébként élettelen idolummá merevedett. De aztán minden következményével együtt hirtelen az országra szakadt 1918-19 tragédiája, s a nagy összeomlás robajában Széchenyi szobra is megrázkódik. „Egyszerre rettenetesen elevenné lesz. „Szólamai*, "szóvirágai*, *egyoldalúságai « borzasztó reálissá tüzesednek. A nemzethalál, a »teljes felbomlảs* kikacagott és vétkes könnyelmǘségnek bélyegzett vad próféciái fölmerednek a nemzet elốtt [...]." Széchenyi ,a saját hamis kultuszának művirágain taposva beledobban nemzete 
rémült szívébe."7 Åm az úgynevezett „boldog békeidōk” nemzedéke még Trianon után sem akart hinni Széchenyinek - állapítja meg Makkai. A millenniumi éra továbbélö mentalitása miatt nem tudta belátni, hogy ami a nemzettel történt, azért maga a nemzet is felelős. Azzal a meggyõződéssel gyászolta az ország megcsonkulását, hogy „véletlen, külsôdleges, végzetes erõ-összeütközéseknek” vált áldozatává „az igaz, a jó, az ártatlan magyar nemzet". A Széchenyitôl oly keményen ostorozott nemzeti fogyatkozásokról, a Nagy Parlag ezerféle „égig erô giz-gaz”-áról továbbra sem akart hallani. Megpróbálta Széchenyit visszaparancsolni szoborrá. Csakhogy ez most már nem sikerült neki. A történelmi kataklizma nyomán ugyanis a nemzet jövơjét munkáló társadalmi rétegekben mindinkább gyökeret vert a kritikai magyarságszemlélet, s ehhez kapcsolódva új tartalmú Széchenyi-kultusz honosodott meg. A Hitel szerzôjének szellemi redivivusát, a magyarságtól ốszinte önvizsgálatot követelố Széchenyi fölfedezését a nemzet fennmaradásának végsõ nagy kérdése motiválta - irja Makkai. Az a döbbenetes felismerés húzódott meg a háttérben - újra csak Makkait idézzük -, hogy „ha Széchenyi sötét próféciái még egyszer kénytelenek lesznek megvalósulni, akkor nincs többé magyar jövendô"8.

Amit Makkai Sándor az elsõ világháborút követő esztendôk magyarországi Széchenyikultuszával kapcsolatosan 1933-ban esszéisztikus megközelítésben és emelkedett-alanyias stílusban elmondott, azt közel háromnegyed évszázad távlatából a mai eszmetörténeti irodalom némileg másképpen tárgyalja és értékeli. Egyértelmũen megállapítható, hogy a húszas évek elején Széchenyi neve egy fölöttébb sokrétũ ideologizációs folyamat alapvetõ kellékeként került a magyar szellemi élet középpontjába: az ország talpraállításán fáradozó $\mathrm{s}$ a bethleni konszolidációban érvényre jutó konzervatív reformizmus igyekezett Széchenyi igéibôl világnézeti bázist teremteni magának. Az a társadalmi-politikai törekvés épített Széchenyi tettei és kezdeményezései köré átfogó nemzeti ideológiát, amely keresvén az ország számára a válságból való kivezetố utat, azt egy higgadt és körültekintổ antiliberális retardációban, az úgynevezett „keresztény európai szellemhez” és „a hagyományos magyar értékekhez" való visszatérésben vélte megtalálni. Számára a Széchenyi nevében szorgalmazott kritikai nemzetszemlélet voltaképpen a XIX. században meghonosodó s a magyarságra nézve - úgymond - semmi jót nem hozó liberalizmus és szabadelvũség birálatát jelentette.

Ennek az ideológiának a megalapozásában, közelebbrő̉l pedig Széchenyinek a keresztény konzervativ reformizmus és a "spirituális magyarság" képviselổévé való átstilizálásában köztudomásúlag a korszak mindmáig legnagyobb hatású történetírója, Szekfú Gyula játszotta a vezetố szerepet. Szekfử 1920-ban kiadott nevezetes mưve, a Három nemzedék nemcsak a magyar historiográfia Széchenyi-szemléletét határozta meg mintegy másfél évtizedig, hanem egy idõre úgyszólván az egész magyar szellemi élet fejlő̉désének irányt szabott.

Szekfü Gyula történetírói munkásságáról eddig is sokat vitatkoztak, s bizonyára ezután is sokat fognak még vitatkozni a szakemberek. Bárki bármiként értékelje is a munkásságát, azt tiszta lelkiismerettel senki kétségbe nem vonhatja, hogy a huszadik század egyik legnagyobb magyar történésze volt. A magabiztos szaktudás és a lenyũgözổ forrásismeret olyan szintetizáló látásmóddal s a száraz adatok átszellemítésének olyan mũvészi képességével társult nála, amilyenrôl kevés historikus esetében beszélhetünk. A

7 Makkai Sándor: Harc a „szobor” ellen. EH. VI(1933). 3. sz. 150. Kötetben Makkai Sándor: Az élet kérdezett. Tanulmányok I. Bp. 1935. 85.

8 Uö, kötetben 85-86. 
Hârom nemzedék az elsõ világháború utáni magyar szellemi kultúra egyik legfontosabb és legjellegzetesebb produktuma volt. A konszolidáció éveinek magyar szellemi életébôl szinte semmit sem érthet meg az, aki figyelmen kívül hagyja ennek a hatalmas ismeretanyagra támaszkodó $\mathrm{s}$ publicisztikai lendülettel megírt munkának a kortársakra gyakorolt rendkívül nagy hatását.

A Három nemzedék tagadhatatlanul szubjektivitásból született: az a hangulat csapódott le benne, amely a háborús összeomlást és az ország nagy megszaggattatását követõen a katasztrófa okain tûnôdổ s a talpraállás lehetôségein gondolkodó értelmiségiek egy részét, a politizálást felelősségteljes dologként kezelổ közügyi konzervativizmust jellemezte. Kosáry Domokos egyik régebbi megfogalmazása szerint Szekfũ Gyula munkája

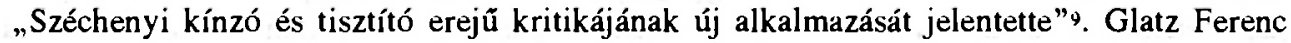
friss keletũ értelmezése szerint pedig a Három nemzedék, kiváltképpen a könyv Széchenyirôl szóló része „egy lelki békétlenségben élô író” műve volt. ${ }^{10}$

Szekfü munkájának az a - nézetünk szerint minden elemében hamis, sổ már a logikai premisszáit tekintve is félrevezetố - tétel állott a középpontjában, hogy a reformkortól kezdve az 1848-49-es forradalmon és a kiegyezésen át el egészen az elsô világháborúig a magyarság története folyamatos hanyatlást mutat. Az 1867-es kiegyezés után - Szekfũ szerint - különösen szembeszökơvé vált a dekadencia, aminek aztán szükségképpen nemzeti tragédiába kellett torkollnia. Szekfü nem hisz a társadalomfejlốdés polgári modelljében, megkérdôjelezi a haladás gondolatát, s határozottan elveti a liberális állami berendezkedés eszményét. Különösen kemény elmarasztaló szavakat használ a magyar liberalizmus, a kiegyezés évtizedeiben létrejövổ gazdaságı és politikai struktúrák értékelésekor. A vádjai e tekintetben a köré a gondolat köré csoportosulnak, hogy a szabadverseny játékszabályaihoz igazodván, a XIX. század második felének liberális állama a polgárság nélküli magyar társadalmat kiszolgáltatottá tette $s$ a magyar embert magára hagyta, amikor annak védelemre lett volna szüksége. Ebbōl a gondolatból kiindulva ítél meg Szekfü csaknem mindent, ami a századforduló Magyarországán gazdasági, politikai és müvelổdési téren történt vagy lejátszódott, kezdve a magyar nagyvárosi kultúra kialakulásával s el egészen a zsidó asszimiláció kérdéséig.

Ezt az itt vázolt társadalomértelmezést és történelmi koncepciót hivatott aláboltozni a Härom nemzedékben Széchenyi István megidézése. A keresztény konzervatív reformizmus szellemében végzett céltudatos országszervezổ munka, a politikai szélsôségek indulatteli logikáját és a haszonelvũ burzsoázia hideg racionalitását egyként elutasító nemzetépítõ tevékenység számára próbált Szekfũ ideológiát alkotni, s ehhez volt szüksége - nem „a legnagyobb magyar”, hanem - „a leghívebb magyar” alakjára. Széchenyivel indít a Három nemzedék elsô, 1920-as kiadásának már a bevezetése is: arra hívja fel itt Szekfü az olvasóját, hogy „vesse le, ha még vannak, illúzióit, s próbáljon meg velem együtt a Széchenyi Istvántól annyit sürgetett nemzeti önismeret útjára lépni”. Szembe kell nézni ôszintén a valósággal, még ha esetleg fájó is az - folytatja Szekfũ -, mert "nemzeti csapások idején nincs más honszeretet, mint az önismeret" I. Persze ez az „önismeret”, mint már jeleztük, Szekfü számára elsốsorban a XIX. század második felének és századunk elejének társadalmi-politikai „tévelygéseivel”, a „gyeplötlen liberalizmussal” és az „üresjáratú szabadelvüséggel” való leszámolást jelentette. A kiegyezés korának

9 Kosáry Domokos: A történetíró. Magyar Szemle 1943. 5. sz. 236.

10 Glatz Ferenc: Három nemzedék története a hetedik nemzedék szemével. Elöszó a Három nemzedék és ami utána kövelkezik 1989 -es reprint kiadásához. XV.

II Szekfü Gyula: Három nemzedék. Egy hanyatló kor története. Bp. 1920. 
vezetô politikusait és literátus tollforgatóit sok mindenért elmarasztalja Szekfũ, de leginkább talán azért, mert - úgymond - meghamisították, a maguk közéleti látásmódjához igazították Széchenyit: liberális reformert csináltak belôle. Figyelmen kívül hagyták azt a hatalmas szakadékot, amely Széchenyit és Kossuthot, illetve az általuk képviselt közügyi éthoszt és társadalmi gyakorlatot elválasztotta egymástól. „Két jelesünket - írja Szekfü - a weimari Goethe-Schiller szobor hasonlatosságára, baráti kézfogásban ábrázolták, minek egyszerū következménye lởn, hogy sem egyiket, sem másikat maga valóságában nem ismerte közönségünk." Az igazság az - szögezi le a Három nemzedék írója -, hogy Széchenyi "diametrálisan ellenkezője volt annak, minőnek a hanyatló kor, saját lelkiismeretének elaltatására, elképzelte"12. Konzervatív reformer volt Széchenyi, a katolikus univerzalizmus és az európai keresztény-germán szellemiség reprezentánsa, ám egyszersmind „a leghívebb magyar”, aki — miközben a társadalom megújhodásáért dolgozott -, „a magyar talajt soha el nem veszti lábai alól” — állapítja meg Szekfü. Majd így folytatja: „Ö nem a viszonyokat, nem az alkotmányt, a politikai és gazdasági berendezkedést óhajtá megváltoztatni, tehát nem az objektív, külsöleges, kézzel tapintható magyar világot, hanem a lelkieket, a magyarság egész belsô szubjektív világát. Reformmunkája elsősorban az egyes magyar lelki diszpozícióinak megjavítására s ezáltal az egyedekbổl kialakuló nemzeti lélek megnemesítésére irányul."13 „Az ổ rendszere csak idổnként, tünetileg, a körülményekhez simultán látszott gazdasági, politikai, magánjogi, kereskedelmi reformnak, holott mindezen pozitívumok csak külsö formái, változó öltönyei valának az állandó erkölcsi gondolatnak." 14 Midốn Széchenyi a Nagy Parlagot ostorozza, voltaképpen a Nemzeti Erény kialakításán fáradozik. „A nemzeti vétkek ellentéte, a nemzeti erény a cél, melyet õ szédítõ magasságban, a lelki élet erkölcsi régióiban helyez el, mérhetetlen távol a kiindulóponttól, a Nagy Parlagtól."ıs

Még hosszasan lehetne folytatni a Három nemzedék szemléleti jellemzöinek és a hozzájuk kapcsolódó Széchenyi-értelmezésnek a bemutatását, s ugyancsak hosszasan el lehetne idôzni Szekfũ Gyula történelemfelfogásának bírálatánál is, de már az eddigi fejtegetéseinkkel is jócskán kiléptünk a tanulmányunk címében megjelölt tematikai keretek közül. Elengedhetetlenül szükség volt azonban erre, mert csak az egyetemes magyar mũvelő̃és általános mozgásfolyamataival egybevetve érthetjük meg igazán az erdélyi magyar kultúra sajátságait. Szekfû̉ áttetsző̉en ideologikus célzatú Széchenyiábrázolásának, illetve a húszas évek magyarországi Széchenyi-kultuszának ismertetése a két világháború közötti erdélyi magyar Széchenyi-recepció eszmetörténeti összefüggéseit hivatott kitapinthatóvá tenni.

Visszatérve dolgozatunk tulajdonképpeni tárgyához, mindenekelôtt azt kell megállapítanunk, hogy a kisebbségi életalapozás évtizedében Szekfü Gyula Széchenyiszemléletének és a hozzá kapcsolódó közügyi értékmagatartásnak az erdélyi magyarság körében nem volt számottevõ hatása. A háború pusztítása, a forradalmak felviharzása és a trianoni trauma nyomán kialakuló magyarországi Széchenyi-kultusznak a húszas évek Erdélyében nemigen voltak követôii. A nemzetı tragédia okozta bénultságból viszonylag hamar magához térö erdélyi magyarság figyelmét más gondok és más feladatok kötötték le: ki kellett építenie a kisebbségi élet számára nélkülözhetetlen társadalmi infrastruktúrákat, politikai, gazdasági és mû̉velổdési téren egyaránt ủi intézményeket kellett létre- 
hoznia. A polgári-plebejus és októbrista értelmiségiek, akik e rendkívül nehéz és nem kevés áldozatot követeló munkában élenjáró szerepet vállaltak, az 1919 utáni magyarországi politikai fejleményeket fenntartással vagy éppenséggel ellenszenvvel szemlélték, s a velük összefüggổ szellemi-ideologizációs törekvéseket is elutasították. Az októbristák inkább Kossuthot idézték, semmint Széchenyit, a transzilvanisták pedig Cserei Mihályra és Apor Péterre, Apáczai Csere Jánosra és Misztótfalusi Kis Miklósra, valamint az önálló Erdély hajdanvolt nagy fejedelmeire, Bethlen Gáborra és a Rákócziakra hivatkoztak közügyi eszmefuttatásaikban. A konzervatív rétegek sem törổdtek különösebben „Széchenyi igéivel". Szemléletükben a Szekfütôl oly szenvedélyesen bírált liberális korszakhoz kötôdtek, annak értékpreferenciáit és mentalitásstruktúráit hordozták magukban, idegen és elfogadhatatlan volt számukra a Három nemzedék megközelítésmódja.

Mindez persze korántsem azt jelenti, hogy a kisebbségi életalapozás gondjaival küszködvén, az erdélyi magyar kultúra nem vett tudomást a húszas években Szekfũ Gyula tevékenységérổ, vagy hogy Széchenyi alakja ez idốben teljesen kihullott az erdélyi magyarság történeti tudatából. Szó sincs ilyesmirổl. Noha 1919 után Erdély hosszú évekre szigorú szellemi vesztegzár alá került, $s$ a magyarországi könyveket és sajtókiadványokat az új hatalom egyáltalán nem engedte át a határon, az erdélyi magyar írástudók igyekeztek mégis számon tartani mindent, ami az anyaország kultúrájában történt. Rendszerint azokat a szellemi-kulturális megvalósításokat és mũvelôdéspolitikai törekvéseket is regisztrálták, amelyekkel nem tudtak egyetérteni. Szekfü Gyula történetírói mũködését az erdélyi magyar tudományosság, a céhbeliek szũkebb rétege úgyszólván kötelességszerüen figyelemmel kísérte, de az értelmiség szélesebb tábora is odafigyelt rá. Szekfü 1924-ben kiadott Történetpolitikai tanulmányok címũ gyũjteményes kötetérôl, amely a Három nemzedék néhány alaptételét fogalmazta újra sarkított formában, terjedelmes kritikai ismertetést közölt a Magyar Kisebbség16. Az 1926-ban megjelentetett, sok szempontból úttörô jelentôségư Iratok a magyar allamnyelv kérdésénék történetéhez címũ Szekfũ-munkából hosszú részletet is közölt Jakabffy Elemér folyóirata. ${ }^{17}$ Ez utóbbi munkát a György Lajos szerkesztette Erdélyi Irodalmi Szemle mindjárt a megielenése után ugyancsak kimerítỏen ismertette és méltatta. 18 Hangsúlyoznunk kell, hogy a pozitív méltatások elsốsorban a szaktörténész Szekfũ Gyulának, a lenyũgöző̉en sokat tudó és megejtóen szépen író historikusnak szóltak. Az ideológus Szekfũvel nemigen törổdtek. vagy fenntartással viszonyultak hozzá. Jellemzổnek érezzük e tekintetben a Magyar Kisebbség 1924. évi utolsó számának a Történetpolitikai tanulmányok kapcsán megfogalmazott következố mondatát: „Mi, akik a képet, melyet a szerzỗ a trianoni Magyarország társadalmi alakulatáról történeti valósággal, finom szociológiai érzékkel elibénk rajzol, a távolból nézzük, akik a társadalmi eszmék eme tusáját azok hatókörén kívül, a magunk szũkös kisebbségi páholyából megvesztegethetetlenül szemléljük s ítéletünket [...] elfogulatlanul formulázzuk - kétkedő meg nem értéssel állunk a zárókövetkeztetések elổtt." 19

Amiként a húszas évek erdélyi magyar kultúrájában Szekfũ Gyula értékelésekor elkülönült egymástól a szakembernek kijáró elismerés és az antiliberális retardáció

16 ( rom.): Szekfü Gyula: Történetpolitikai tanulmányok. MK. III(1924). 24. sz. 979-982.

17 Az erdélyi államnyelv kifejlódése. Szekfü Gyula: lratok a magyar államnyelv kérdésének történeténez 1790-1848. MK. V(1926). 17. sz. 637-642.

18 Apor Péter: Szekfü Gyula: Iratok̉ a magyar államnyelv kérdésének történetéhez 1790-1848. Erdélyi Irodalom Szemle (a továbbiakban: EISz) III(I926). 20I-206.

19 MK. III(I924). 24. sz. 98 I . 
ideológusától való idegenkedés, azonképpen a korszak erdélyi magyar Széchenyiirodalmában is sajátos szemléleti kettôsség figyelhetố meg. Eszmetörténeti összefüggéseiben vizsgálva, illetve az egyetemes magyar szellemi mūveltség egykori törekvéstendenciáival összevetve kisebbségi kultúránkat, arra a megállapításra jutunk, hogy az elsố világháborút követố évtized ideologikus fogantatású Széchenyi-divatja elkerülte Erdélyt. Mint már fentebb is mondottuk, nem hullott ugyan ki Széchenyi alakja az erdélyi magyar történeti emlékezetbôl, de Erdélyben jóval kevesebbet $s$ merôben más megközelítésben foglalkoztak vele, mint Magyarországon. Ami Erdélyben a húszas években Széchenyirōl megjelent, azt elsôsorban a nemzeti történelem minden nagyjának kijáró tisztelet, nem pedig valamilyen ideológiateremtő szándék diktálta. Széchenyi eszméinek aktuálpolitikai-ideológiai megpörgetésére, ami Szekfư Gyula Härom nemzedèke nyomán a bethleni konszolidáció időszakában Magyarország szellemi kultúrájának egyik jellemzō vonásává vált, a húszas évek Erdélyében nemigen találunk példát. Volt ugyan Erdélyben is hasonló megpörgetés, de az más históriai nagyságokhoz, a közösségi géniusz más reprezentánsaihoz kapcsolódott. A múltbeli események normatív megjelenítése, az elôdök tetteinek és törekvéseinek a jelen feladataival való szembesítése itt más módon és más mércék alapján történt. Valahogy úgy, ahogyan azt Kristóf György egyik 1929-es írása, pontosabban az írás címének Tompa Mihálytól kölcsönzött sajátságos metonímiája példázta. Erdély Széchenyi Istvánja - ezt jegyezte címként az Erdélyi Irodalmi Szemlében közölt tanulmánya fölé Kristóf György —, a tanulmányában pedig a XIX. századi Erdély nagy mindenesének, az Erdélyi Múzeum-Egyesület alapítójának, gróf Mikó Imrének a tevékenységét méltatta. ${ }^{20}$

Az elmondottak alkalmasint azt is érthetôvé teszik, hogy a vizsgált idôszak erdélyi magyar sajtójában - ide értve a tudományos kiadványokat is - a Széchenyivel foglalkozó írások miért csak egy-két jubileumi alkalom kapcsán szaporodtak meg. Fôként az elsô reformországgyũlés megnyitásának, Széchenyi közéleti fellépésének és a Magyar Tudományos Akadémia megalapításának 100. évfordulója alkalmából fordult a "legnagyobb magyar” alakja és szellemi öröksége felé a közösségi érdeklốdés. 1925-ben jött volt el a centenáriuma annak, hogy a hosszas huzavona után összehívott magyar országgyưlés 1825 . október 12-i ülésén egy huszár kapitånyi egyenruhát viselổ, eladdig a közélet színpadán egyáltalán nem szereplổ s magyarul akkor még eléggé gyatrán beszélö fôúr azzal lepte meg méltóságviselõ társait, hogy magyar nyelven szólalt fel, s pártját fogta az alsótábla ellenzéki javaslatainak. Rendkívüli dolog volt ez, mert korábban évszázadok óta nem hangzott el magyar szó a fơrendi tábla ülésein. S ugyanez a huszár kapitány két héttel késôbb, 1825. november 3-án, amikor a rendek egyik vezérszónoka, felsőbükki Nagy Pál, a nyelv nemzetfenntartó szerepéröl beszélvén, fölszólította a jelenlévôket, hogy annak ápolását anyagi áldozatokkal is segítsék elõ, azonnal egyévi jövedelmét ajánlotta fel - összesen mintegy 60 ezer forintot - egy alapítandó tudós társaság céljaira. Példáját mások is követték. Így rövidesen negyedmillió forintnyi adomány gyưlt össze, s az országgyũlés külön törvénycikket fogadott el a Magyar Tudományos Akadémia létrehozására. ${ }^{2 !}$

Ismételjük: mindennek 1925-ben volt a 100. évfordulója, s az erdélyi magyar szellemiség, amely a maga megkülönböztetõ sajátságait hangsúlyozva is az egyetemes magyar szellemiség elszakithatatlan részének $s$ az egész kárpát-medencei magyar

20 Kristóf György: Erdély Széchenyi Istvánja. EISz. VI(1929). 328-337.

21 L. Hóman Bálint-Szekfú Gyula: Magyar történet V. Írta Szekfü Gyula. Bp. 1936. 262.: Barta István: A Széchenyi-kérdés. Elöszó Széchenyi István válogatott írásaihoz. Bp. 1959. 9. 
történelem teljes jogú társörökösének tekintette magát, igyekezett méltó módon adózni Széchenyi emlékezetének. Több centenáriumi cikk, múltidézố írás jelent meg ez alkalomból az egykori magyar sajtókiadványokban, s néhány igényesebb tanulmány is napvilágot látott. Csaknem általános jellemzōjük volt e cikkeknek és tanulmányoknak a szemléleti visszafogottság, a nagy fesztávú általánosításokat kerüló, higgadt, analitikus megközelítésmód és a történetiség elvének messzemenô respektálása. Nézetünk szerint korántsem csak a kisebbségi helyzettel összefüggõ publikációs körülmények késztették szordínós hangvételre a cikkírókat és a tanulmányok szerzôit: az a különbség ragadható meg itt, amely a húszas évek erdélyi magyar Széchenyi-szemléletét az egykori magyarországi Széchenyi-kultusztól elválasztotta.

Emeljünk ki egyet-kettốt az említett többszörös Széchenyi-évforduló kapcsán publikált fontosabb és jellemzõbb írások közül.

Az Erdélyi Irodalmi Szemle 1925. évi elsố számában jelent meg Borbély Istvánnak, a kolozsvári unitárius kollégium egykori kiváló tanárának, a jeles irodalomtörténésznek és irodalomszervezônek az ünnepi cikke Gróf Széchenyi István címmel és a következö alcímmel - az ezópusi nyelv itt talán már valóban kényszerüséget fejez ki, a kisebbségi megnyilatkozásokat körülpalánkoló cenzúra szigoráról $\mathrm{s}$ egyszersmind annak ostobaságáról tanúskodik -: Az 1825-ik év eseményeinek centenáriuma alkalmából. Szolid, tárgyilagosságra törekvõ írás, a pozitivizmus tudományeszménye szabja meg a gondolatmenetét. Elsốsorban a homo oeconomicus Széchenyi Istvánt mutatja be, a gyakorlati kezdeményezések emberét, aki a nemzeti felemelkedés alapját és legföbb feltételét a gazdasági előrehaladásban látta. Érzékeltetendō Borbély István cikkének tartalmát és szemléletét, úgy hisszük, elégséges lesz néhány sort idéznünk belõle. Így mutatja be Széchenyi gazdaságpolitikai elképzeléseit: ..Reformtörekvéseinek középponti célja az ország iparának kifejlesztése volt. Azonban a helyes iparfejlesztõ politikát okszerũ̃ nemzetgazdászatnak, tehát egyrészt földmũvelésnek és állattenyésztésnek, másfelől hitelképesen rendezett pénzügynek kell megelōznie és a közbiztonság jogrendjén álló kereskedelemnek kell követnie. Ennélfogva az iparpolitikának $s$ rajta keresztül a nemzeti haladásnak [olyan] programja van, melyben nemcsak a mi, hanem a miként is alapvetổ fontosságú, mi több, a cél elérése egyenesen a helyesen megválasztott $\mathrm{s}$ az okosan betartott módszertôl függ. "22

Balogh Artúr tolla alól került ki az a másik, Széchenyit idézõ évfordulós írás, amelyet érdemesnek tartunk a feledés homályából kiemelni. Az elsỗ világháború utáni erdélyi magyar közélet neves képviselóje, a kisebbségjog európai viszonylatban is nagyra becsült egykori szakértôje az Erdélyi Irodalmi Társaság 1925. december 6-i ülésén Széchenyi emlékezete címmel terjedelmes tanulmányt olvasott fel, melyet aztán nem sokkal késõbb az Erdélyi Irodalmi Szemle nyomtatásban is leközölt. 3 Nézetünk szerint valahány írás közül, ami a húszas években Erdélyben Széchenyirôl megjelent," a Balogh Artúré mondható a legigényesebbnek. Kiegyensúlyozott és tárgyilagosságra törekvõ elemzést nyújt, s igyekszik a maga sokrétũségében bemutatni Széchenyi tevékenységét. Tanulmányának igényes voltát mi sem bizonyítja jobban, mint az, hogy a fejtegetéseivel és következtetéseivel nagyrészt a mai olvasó is maradéktalanul egyetérthet.

22 Borbély István: Gróf Széchenyi Ist án. - Az 1825-ik év eseniényeinek centenáriuma alkalmából. EISz. LVII(1925). 1.

23 Balogh Artúr: Széchenyi emlékezete. EISz. LVII(1925). 393-410. Tanulmányát Balogh Artủr késő̉bb részint bốvítve, részint pedig átdolgozva - kötetté formálta: Széchenyi István. Cluj-Kolozsvảr 1936. (A Magyar Nép Könyvtára). 
Balogh Artúr ki nem mondottan bár, de egyértelmưen szembehelyezkedik azzal az inkább publicisztikai fogantatású, de a szellemtörténeti irányzat révén a tudományosságba is beszüremlõ állásponttal, mely szerint Széchenyiben „minden magyar sorskérdés idôtlen megválaszolóját" kell látnunk. Már a tanulmánya bevezetố soraiban leszögezi, hogy Széchenyi, s mindaz, ami az ở nevéhez kapcsolódott, sajátságosan a XIX. század elsổ felének magyar történelmét reprezentálta. „Csak abban a korban, csak a magyar társadalomnak ama viszonyai között lehetett azzá, amivé lett" - írja érezhetôen polemikus éllel Balogh Artúr, majd a megállapítását így nyomatékosítja: „Az a kor kellett, hogy nemzetének prófétája, megváltást hirdetője, az ígéret földjét megmutatója legyen. Azok a viszonyok kellettek, hogy a *legnagyobb magyar legyen." 4

Széchenyi közügyi szemléletét és közösségi-közéleti tevékenységét taglalva, Balogh Artúr erôteljesen aláhúzza $-\mathbf{s}$ ebben is felfedezhetô némi polemikus szándék - hogy a nagy reformer nemzeti megújulásprogramja a társadalmi szervezet minden szféráját egyformán átfogta, az anyagi és erkölcsi, a gazdasági és mũvelổésbeli modernizáció követelményeit egyként szem elổtt tartotta. Hasonló határozottsággal emeli ki Balogh Artúr a nemzetinek és az általános emberinek a szerves összefonódását is Széchenyi világlátásában. Alkalmasint nem lesz érdektelen és tanulságok nélkül való szó szerint idéznünk, hogy a magyarság reformkori magára találása, illetve a magyar nemzeti fejlödés XIX. századi nekilendülése szemszögébōl miként határozza meg Balogh Artúr túl a kézzelfogható közéleti érdemeken - Széchenyi jelentôségét. „Nagy jelentôsége mindenekelỡt abban áll - írja —, hogy ổ rázta fel a magyar nemzetet abból a dicsô múltból táplálkozó optimista illúzióból, amely azt hitte, hogy ha eddig el nem pusztult annyi vész és megpróbáltatás után a magyar, eddigi állapotában is képes lesz megállni helyét ezután is. $\mathrm{O}$ rázta fel abból a tévhitbổl, hogy szellemileg és anyagilag egyaránt hátramaradás, káros intézmények nevetséges magasztalása, kis privilégiumok bálványozása mellett a jövốben is meg lehet élni."-s Fölismerte és következetesen hirdette, hogy „a magyar nemzetnek is korszerũen át kell alakulnia, ha fenn akar maradni..."26

Ha valaki a kimerítõ teljesség igényével próbálná számba venni a húszas évek erdélyi magyar Széchenyi-irodalmát, az még több más cikket, tanulmányt, múltidézô eszmefuttatást cédulázhatna ki az egykori sajtóból, sổt néhány írói-költỗi alkotást is fölleltározhatna a témában. Kezdve a történész és irodalomtudós Bitay Árpáddal, aki a szóban forgó időszakban mintegy féltucatnyi cikkben foglalkozott Széchenyi alakjával és tevékenységével, igyekezvén összekalászolni minden apró adatot, ami a Hitel, a Világ és a Stádium eszméinek XIX. századi román recepcióiáról, illetve Széchenyinek a román szellemiségben való jelenlétérôl tanúskodik27, el egészen a gyulafehérvári Majláthfổgimnázium egykori tizenhét esztendốs diákjáig, aki - ma már nem szívesen eĵ̣ük ki a nevét - a Pásztortüz 1925. március 8-i számában csikorgó klapanciákban adózott a „legnagyobb magyar” emlékezetének28, jó néhány szerzổ szerepelhetne egy exhausztív igénnyel összeállított Széchenyi-bibliográfiában. Jelen dolgozatunk keretei között azonban

24 I.m. 393.

25 I.m. 395-396.

$26 \mathrm{l} . \mathrm{m} .396$.

27 Bitay Árpád: Gróf Széchenyi Istvánnak és apjának híre és egykorí ismertetése Romániálan. EISz. I(1924). 136-141: Széchényi [!] és a románok. Pászlortüz'(a lováhbiakban: P1) XI(1925). 475-476.: Az elsố román folyóirat Széchenyi Istvánról. E. 1926. 171. sz.: Román dicsổiổ írás és vers a Széchenyiekrổ 1829-bôl. EISz. V(1928), 84-98; Még egy román kortárs magaszaló megemlékezése Széchenyi István;ól. Uo. VI(1929). 105-106.

38 Bányai László: Széchenyihez. P1. XI(1925). 85 
nyilván nem lehet célunk a húszas évek teljes erdélyi Széchenyi-irodalmának a föllajstromozása. Erre itt nincs is szükség. Úgy véljük, az emlitett cikkek és tanulmányok, illetve a belôlük kiemelt gondolatok is elégségesen igazolják azt a megállapításunkat, hogy amit Erdélyben az 1918-19 utáni elsõ évtizedben Széchenyirôl írtak, azt - ellentétben a bethleni konszolidáció Magyarországával - nem valamilyen programalkotó törekvés vagy ideológiai útkeresés diktálta, hanem a múlt nagyjainak természetszerũen kijáró tisztelet. Megfelelō támpontot kínálnak e cikkek és tanulmányok ahhoz is, hogy áttekinthessük azokat a gyökeres változásokat, amelyeket a Széchenyi szellemi örökségéhez való viszonyulás tekintetében a harmincas évek hoztak magukkal.

Ezen a ponton visszaérkeztünk oda, ahonnan László Dezsô Akarom: tisztán lássatok címũ, 1933-ban közzétett könyvecskéjének a felemlítésével elindultunk. Mint tanulmányunk elején már mondottuk, a húszas-harmincas évek fordulóján Széchenyi eszmei öröksége az eleven erdélyi magyar szellemi élet középpontjába került, $s$ az egykori fiatal értelmiség egy része belöle kiindulva próbált politikai-világnézeti paradigmát alkotni magának. A nagy gazdasági válság ezerféle feszültségtõl terhes idôszakában s az utána következô esztendốkben, amikor az erdélyi magyarság soraiban is mélyreható polarizálódás ment végbe $s$ többszörös nemzedéki szembenállás szabdalta részekre a kisebbségi társadalmat, Széchenyi invokációja formálisan olyasféle szerephez jutott Erdélyben - ezt is megállapítottuk már -, amilyent Magyarországon a bethleni konszolidáció elsố napjaitól kezdve játszott. A Hitel reformprogramjára való visszatekintés, Széchenyi eszméinek és akarásainak megidézése a harmincas évek erdélyi magyar szellemiségében ideológiai tartalmat $\mathrm{s}$ részint aktuálpolitikai jelentést kapott, egymással szemben álló társadalmi törekvések ütköztetõ tényezõjévé vált.

Vázlatosan ugyan, de szóltunk már az elõzõekben azokról az eszme- és társadalomtörténeti körülményekrôl, amelyek Széchenyi erdélyi utóéletében a jelzett fordulatot előidézték. Itt még arra a kérdésre kell válaszolnunk, hogy kinek a munkásságához vagy milyen szellemi-világnézeti tömörülés tevékenységéhez köthetõ Széchenyi fölfedezése és közügyi éthoszának követendõ példaképpé való avatása. E kérdés kapcsán pedig elōször azt a vélekedést kell megvizsgálnunk, mely szerint az addig járt kisebbségi-közéleti út sehová sem vezetổ jellegére rádöbbenô $s$ mũvelödési téren is válságjelenségrekkel küszködổ erdélyi magyar társadalom Széchenyi felé való fordulását Makkai Sándor kezdeményezte, mégpedig a Magunk reviziỏja címũ 1931-ben kiadott könyvével és az Erdélyi Helikonban közölt, fentebb már többször idézett 1933-as tanulmányával. Pongrácz Kálmán, aki egykor maga is ahhoz a fiatal értelmiségi csoportosuláshoz tartozott, amely Széchenyi nevét a zászlajára írta, úgy fogalmazott, hogy Makkai volt az, aki "Széchenyi keresztény-nyugatmagyar-európai szemléletét" lígy, ahogyan az Szekfũ Gyula és követôi tollán megfogalmazódott, "népi és transylván szellemmel" átültette „keletmagyar-protestáns környezetbe".29

Az erdélyi magyar eszmetörténeti irodalom sok nagy adóssága közé tartozik többek között az is, hogy mind ez idáig nem foglalkozott kellổképpen Makkai Sándor elméletbölcseleti munkásságával. Különösen hiányolandó az, hogy mindmáig nem került sor a Magunk reviziójának alapos és körültekintô, a mũ keletkezésének körülményeit, világnézeti eredõit és ideológiai filiációit egyként szem elốtt tartó elemzésére. Pedig e mũ köztudomásúlag a két világháború közötti erdélyi magyar szellemi kultúra egyik legtöbbet

29 Pongrácz Kálmán: A népi és európai gondolat. Hitel (a továbbiakban: H) 1936. 2. sz. 127. Ugyanezt a gondolatot Pongrácz egy másik irásában is kifejti: Kelet és Nyugat az ifúsági gondolatban. Magyar Szemle 1935. 4. sz. 331-341. 
emlegetett, a harmincas évek útkeresổ fiatal értelmiségére kiváltképpen erốteljesen ható alkotása volt.

Makkai munkájának részletes taglalásáról természetesen itt sem lehet szó. E helyütt mint jeleztük - csak arra a kérdésre kívánunk válaszolni, hogy az erdélyi Széchenyiszemléletben bekövetkezett változás mennyiben kapcsolható a Magunk revíziójának megjelenéséhez. Azt kell tehát megnéznünk, hogy Makkai mũvében milyen mértékben volt jelen Széchenyi eszmevilága vagy annak Szekfư-féle ideologikus interpretációja.

Nos, nézetünk szerint tagadhatatlan, hogy Makkai mondanivalóját jelentôs részben Széchenyi inspirálta, s kétséget kizáróan megállapítható az is, hogy elemzéseiben helyenként Szekfũ Gyula okfejtéseihez igazodott. Makkai kemény kritikai hangvételében, a húszas évek erdélyi közügyi viszonyaival és közéleti állapotával kapcsolatos bírálatában ugyanúgy ott érezzük Széchenyi szellemiségét, mint a "lelki impériumra" vonatkozó felfogásában vagy a magunk hibáiért viselt felelốsség vállalásának következetes szorgalmazásában. Mintha egyenest a Hitel Széchenyijét parafrazálná Makkai, amikor például azt fejtegeti, hogy az erdélyi magyarságnak, ha fenn kíván maradni, ôszintén szembe kell néznie a maga addigi tévedéseivel, $s$ le kell számolnia önnön fogyatkozásaival. „Az élet érdekében el kell fogadni azt a szabályt - szögezi le egy helyütt Makkai, s a szavaiból Széchenyi száz évvel korábbi axiómáját véljük kihallani -, [hogy] ami velem történik, annak sohase keressem és sohase fogadjam el külsô okát addig, amíg csak egyetlen belsô ok is van, ami hozzájárulhatott ahhoz, hogy az a valami megtörténjék." 30

Mindazáltal a Magunk reviziójába beépülő Széchenyi-reminiszcenciák és a munkában itt-ott fölfedezhetõ Szekfü-hatás ellenére azt kell mondanunk, hogy az „új tartalmú Széchenyi-kultuszt" nem Makkai honosította meg Erdélyben. A Makkai kezdeményezõ szerepét valló álláspont szerintünk nem válik elfogadhatóbbá azzal, hogy a Magunk reviziója mellé esetleg odahelyezzük bizonyítékként az író-püspök másik említett publikációját, a Harc a "szobor" ellen címũ 1933-as írását is. Ez utóbbinak a szellemiközügyi érdeklödés Széchenyi felé fordulása tekintetében már pusztán azért sem lehetett úttörổ szerepe, mert lényegében csak szemlecikk volt, s mint ilyen, többek között László Dezsổ jóval korábban megjelent Akarom: tisztán lássatok címũ könyvecskéjéhez füzött megjegyzéseket.

Széchenyi szellemi örökségét s vele együtt annak Szekfũ-féle interpretációját is Erdélyben igazából az 1929-33-as gazdasági világválság idején és az utána következỏ esztendökben színre lépổ fiatal értelmiségi mozgalmak fedezték fel és emelték be az egykori politikai-világnézeti küzdelmek erổterébe. Azok a nemzedéki csoportosulások véltek Széchenyiben ideológiai támaszra és közéleti példaképre találni, amelyek részint az ifjúság örök radikalizmusától, részint nagyon is jogos elégedetlenségtôl hajtva, az addigi kisebbségi politika meddổsége és a kisebbségi kultúra ellaposodása miatt lázadozva, valami újat szerettek volna érvényre juttatni Erdélyben. Makkai könyve, a Magunk reviziója is végsổ soron csak annak a társadalmi-politikai légkörnek és szociálpszichológiai atmoszférának volt a kifejeződése, amely a fiatal értelmiség szellemi „pártütését" a harmincas évek elsô felében elôidézte. A könyvnek messzire hullámzó hatása volt az egész egykori erdélyi magyar müvelő̉ési életben, $\mathrm{s}$ a táborokba szervezổoõ fiatal értelmiségi nemzedék világnézeti önállósulását is nagymértékben elôsegítette, de a Széchenyi-kultusz Erdélyben nem általa született meg. Elsôként, úgylehet, éppen Makkai 
utalt rá, hogy e tekintetben minden érdem és minden esetleges szemrehányás László Dezsőék és Venczel Józsefék nemzedékét, helyesebben mondva a „tisztánlátás" követelményét újrafogalmazó generációs tömörüléseket illeti meg. László Dezsô többször is említett könyvecskéjét méltatva, Makkai, miután aláhúzta, mily fontos fejleménynek tartja, hogy immáron „a fiatalok is beálltak a "szobor" elleni harcba", így fejezte be eszmefuttatását: „Ha a magyar ifjúság teszi élổvé Széchenyit a maga számára, ez döntố jelentôségũ lesz és hatásaiban kiszámíthatatlan áldások forrása. "3ı

A harmincas évek elsõ felének nemzedéki aspirációkkal és általános társadalmipolitikai reformtörekvésekkel egyként fellépổ fiatal értelmiségi csoportosulásai közül három olyant emelhetünk ki, amelyek eszmei-ideológiai fogódzókat keresvén maguknak, kisebb-nagyobb mértékben Széchenyi István történeti örökségéhez nyúltak vissza. Az 1930-ban induló Erdélyi Fiatalok, a felelôs szerkesztôként Koós-Kovács István által jegyzett, de valójában Makkai László és Venczel József által kezdeményezett 1935-ös Hitel és annak egy évvel késôbb született féltestvére, az Albrecht Dezsô-féle Hitel körül szervezôdố fiatal értelmiségi csoportosulásokról van szó. Mint ismeretes, nagyon jelentôs generációs tömörülések, az egykori erdélyi magyar kulturális és közéleti viszonyok alakulását a maga egészében is befolyásoló szellemi-világnézeti szekértáborok voltak ezek.

Terjedelmes és sokrétũ elemzést igényelne annak eldöntése, hogy a jelzett fiatal értelmiségi csoportosulások közül melyik milyen mértékben építette a maga világlátását és közügyi törekvéseit Széchenyire, ki mennyiben ötvözte a „legnagyobb magyar" társadalomfelfogását és nemzetszemléletét másoktól kölcsönzött ideológiákkal, ki miként kapcsolta össze a múlt szellemi örökségét a kisebbségi valóság közvetlenül megélt tapasztalataival. Egy átfogó igénnyel végzett eszmetörténeti vizsgálódásnak feltétlenül válaszolnia kellene arra a kérdésre is, hogy a harmincas évek erdélyi értelmiségi csoportosulásai által elfogadott Széchenyi-értelmezések miként illeszkedtek bele a korszak egyetemes magyar szellemiségébe. Ez utóbbi kérdés kapcsán nyilván óhatatlanul szóba kerülne az a probléma is - a két Hitel-csoportosulás esetében semmiképpen sem lehetne kitérni elöle -, hogy akik Szekfú Gyula látásmódját tették magukévá, azokat voltaképpen melyik Szekfú Gyula inspirálta: az 1920-as Három nemzedék szerzổje-e, vagy pedig az, aki 1934-ben a maga eredetileg négy könyvbôl álló mûvét egy ötödik könyvvel, az 1919-20 ütán kialakuló magyãr „neobarokk” társadalmi és politikai rendszer rendkívül éles hangú, bizonyos fokig még Szabó Dezsốn is túltevố kritikảjával toldotta meg? $\mathrm{S}$ mindezek tisztázása után még ott volna az egykori generációs mozgalmak megítélése szemszögéből a legfontosabb kérdés: akik Széchenyi alapvetỏ munkájának, az 1830-ban megjelent Hitelnek a címét száz esztendố múltán kölcsönvették és folyóiratcímmé avatták, azok mit végeztek az erdélyi magyar kultúrában s mit tettek közéleti téren, egyszóval miként sáfárkodtak Széchenyi szellemi hagyatékával?

Mindezeknek a kérdéseknek a kibontása további tanulmányok sorát, a két világháború közötti erdélyi magyar kultúra és közélet további vizsgálatát követeli meg.

31 Makkai Sándor: Harc a „szobor“ ellen. EH. VI(1933). 3. sz. 163. Kötetben Makkai Sándor: Az élet kérdezett. Tanulmányok I. Bp. 1935. 103. 
Idézettel kezdtük a tanulmányunkat, $s$ idézettel fejezzük be. Az 1935-ös Hitel beköszöntô számának elsổ oldalán Makkai Sándor Mi lesz velünk? címũ cikkét s Szekfũ Gyula Három nemzedék és ami utána következik címũ müvének egyik igen fontos alfejezetét, nevezetesen a "nagymagyar út"-tal, vagyis az egyenes tartású, tiszta öntudatú, kimũvelt, magyarabb magyarság megteremtésével kapcsolatos fejtegetését találta az egykori olvasó. A második lapon jelent meg Juhász István félig-meddig programadó írása, ugyancsak Hitel címmel. Ennek elsô mondatait idézzük. E mondatok nyilván elsổsorban a több mint félszázaddal ezelổtti lapindítók helyzetértékelését, létérzetét és intellektuális tájékozódását fejezik ki, s számunkra kissé tán a szófüzésük is szokatlannak tetszik. Ám ennek ellenére van valami olyasmi bennük, vagy talán inkább mibennünk, a magunk mai közösségi létkörülményeiben található valami olyasmi, ami részben aktualitást kölcsönöz nekik. Ezt írta Juhász István: „Ma Széchenyi-divat tartja uralma alatt a magyar földet. A mi számunkra azonban Széchenyi többet jelent. Saját korának kérdéseivel szembeni álásfoglalása minket, kik ugyanazon folyam: a magyar élet sodrában, az övéhez hasonló korban állunk, tanított, nevelt, kérdéseinket megvilágította. Széchenyi életünknek kiszakíthatatlan részévé lett és gondolkodásunk kiindulási pontjává.

Fájdalmasan és élesen látja meg Széchenyi, hogy a magyarság élete kopár, parlagi, *a halhatatlan lélek« ítélôszéke elổt értéktelen, semmi. A nagy Parlag magyarázatát, e roppant süllyedés okait nem kívül keresi: belïil, a nemzeti bünökben találja meg. Széchenyi nemzeti önkritikája így saját helyzetünk öntudatos felismerésére is indít." ${ }_{32}$ 